\title{
Prediksi Probabilitas Perusahaan Berdasarkan Perputaran Kas dan Perputaran Modal Kerja Pada Perusahaan Makanan Dan Minuman Yang Terdaftar Di Bursa Efek Indonesia (BEI) Periode 2014-2017
}

\author{
Aria Aji Priyanto \\ Program Studi Manajemen, Universitas Pamulang, Tangerang Selatan \\ email: aria.aji@gmail.com
}

\begin{abstract}
Abstrak. Penelitian ini bertujuan untuk mengetahui pengaruh Perputaran Kas dan Perputaran Modal Kerja terhadap Profitabilitas dengan pengukuran Return on Investment (ROI) pada Perusahaan Makanan dan Minuman yang terdaftar di Bursa Efek Indonesia (BEI) periode 20142017. Jenis penelitian adalah riset kausalitas dengan pendekatan kuantitatif. Metode analisis data menggunakan analisis regresi data panel dengan teknik estimasi uji Chow, uji Hausman dan uji Lagrange Multiplier (LM) kemudian dilanjutkan dengan uji hipotesis. Hasil penelitian menunjukkan bahwa Perputaran Kas dan Perputaran Modal Kerja secara simultan dan secara parsial tidak mampu memprediksi profitabilitas perusahaan berdasarkan pengukuran Return On Investment (ROI).
\end{abstract}

Kata kunci: perputaran kas, perputaran modal kerja, return on investment.

\section{Pendahuluan}

Perusahaan makanan dan minuman merupakan salah satu kategori sektor industri di Bursa Efek Indonesia (BEI) yang mempunyai peluang untuk tumbuh dan berkembang. Industri yang tumbuh dan berkembang secara cepat dan dinamis mengharuskan perusahaan untuk terus mempertahankan dan meningkatkan kinerja perusahaan. Tidak menutup kemungkinan untuk perusahaan-perusahaan yang bergerak dalam bidang industri makanan dan minuman. Barang konsumsi menjadi industri yang penting bagi perkembangan perekonomian bangsa (Kementerian Perencanaan Pembangunan Nasional/Badan Perencanaan Pembangunan Nasional, 2018). Perusahaan makanan dan minuman merupakan perusahaan yang bergerak dibidang pembuatan produk, dari bahan mentah menjadi barang jadi atau barang setengah jadi kemudian dijual, Pencapaian tujuan tersebut, baik untuk meningkatkan kekayaan pemilik ataupun untuk mengembangkan perusahaan merupakan aktivitas-aktivitas yang memerlukan dana atau kas. Oleh karena itu, agar tujuan tersebut dapat dicapai secara efektif dan efesien, maka salah satu keadaan yang harus di capai adalah perusahaan harus memiliki laba atau 
dengan kata lain perusahaan harus memiliki profitabilitas yang tinggi dari operasinya. Profitabilitas disini diartikan sebagai kemampuan perusahaan untuk memperoleh laba dari kegiatan operasi pokoknya (Siti, 2018).

Keputusan investasi ini merupakan keputusan yang sangat penting, karena investasi merupakan kekuatan penggerak utama dari setiap sistem usaha. Keputusan operasi merupakan keputusan yang berhubungan dengan penggunaan sumber daya yang dimiliki, pemilihan pasar, penetapan harga produk, efisiensi biaya, dan lain-lain. Keputusan pembiayaan berkaitan dengan keputusan manajemen untuk membiayai investasi dan operasi usaha dalam jangka panjang termasuk didalamnya antara lain keputusan penggunaan kas dan struktur modal (Arifianti, hal. 1.1). Penggunaan kas pada perusahaan ada istilahnya siklus konversi kas, siklus ini adalah interval waktu antara pengeluaran kas untuk pembelian bahan baku sampai dengan waktu terkumpulnya kas dari hasil penjualan produk. Siklus konversi kas diukur sebagai penjumlahan dari waktu lamanya kas terikat dalam persediaan dengan waktu lamanya kas terikat dalam piutang dikurangi dengan waktu lamanya penundaan pembayaran utang ke pemasok. Siklus konversi kas ini hampir sama dengan perputaran kas yang dimana semakin tinggi atau cepat perputarannya itu semakin baik artinya perusahaan semakin cepat mendapatkan pendapatan dari hasil penjualan atau investasi yang masuk ke kategori kas.

Perputaran kas ini juga harus dilihat berdasarkan laporan arus kas yang dibuat oleh perusahaan, agar pimpinan perusahaan mampu menganalisis keuangan pada perusahaan. Dengan analisis tersebut maka akan dapat diketahui berapa besar dana yang dibutuhkan agar mampu membiayai kegiatan operasional perusahaan dan dapat memungkinkan perusahaan beroperasi seefisien mungkin serta dapat mengontrol kesulitan keuangan. Laporan arus kas ini menggambarkan suatu penerimaan, pengeluaran kas dan saldo akhir kas dalam suatu periode untuk digunakan sebagai pertanggung jawaban dan pengambilan keputusan. Laporan ini juga menyajikan informasi mengenai penerimaan dan pengeluaran kas yang berkaitan dengan aktivitas operasi dan investasi aset non keuangan (Mukhtarom, Kusumaningrum, \& Ifanani, 2015).Setiap aktivitas yang dilaksanakan oleh perusahaan akan selalu memerlukan dana, baik untuk membiayai kegiatan operasional sehari-hari maupun untuk membiayai investasi jangka panjangnya. Dana yang digunakan untuk melangsungkan kegiatan operasional sehari-hari perusahaan disebut modal kerja. Modal kerja dibutuhkan oleh setiap perusahaan untuk membiayai kegiatan operasinya sehari-hari, dimana modal kerja yang telah dikeluarkan itu diharapkan akan dapat kembali lagi masuk dalam perusahaan dalam waktu yang pendek melalui hasil penjualan produksinya (Bulan, 2015).

Manajer juga perlu mengetahui tingkat perputaran modal kerja agar dapat menyusun rencana yang lebih baik untuk periode yang akan datang. Selain manajer, kreditor jangka pendek juga perlu mengetahui tingkat perputaran modal kerja suatu perusahaan. Dengan begitu, kreditor jangka pendek akan memperoleh kepastian atau jawaban kapan hutang perusahaan akan segera dibayar. Manajemen modal kerja dalam suatu perusahaan diperlukan untuk mengetahui jumlah modal optimal yang dibutuhkan perusahaan tersebut. Manajemen modal dalam hal ini biasanya ialah kegiatan yang mencakup semua fungsi manajemen atas aktiva lancar dan kewajiban jangka pendek perusahaan. Adapun sasaran yang ingin dicapai dari manajemen modal kerja yaitu untuk memaksimalkan nilai perusahaan dengan mengelola aktiva lancar sehingga tingkat pengelolaan investasi marjinal adalah sama atau lebih besar dari biaya modal yang digunakan untuk membiayai aktiva tersebut (Bulan, 2015). Kegunaan ini berkaitan dengan penggunaan modal kerja yaitu mengupayakan agar modal kerja yang tersedia tidak kelebihan dan tidak juga kekurangan. Untuk dapat menentukan jumlah modal kerja dalam pengelolaannya perlu diperhatikan tiga elemen penting yaitu kas, piutang dan persediaan. Dari semua elemen tersebut dihitung perputarannya. Semakin cepat tingkat perputaran yang terjadi pada masing-masing elemen modal kerja, maka modal kerja dapat dikatakan efisien. Tetapi jika 
perputarannya semakin lambat, maka penggunaan modal kerja dalam perusahaan kurang efisien. Dalam penelitian ini elemen modal kerja yang akan dibahas adalah kas. Kas dalam perusahaan ialah salah satu unsur yang paling tinggi tingkat likuiditasnya (Marantika, 2015).

Modal kerja yang cukup menjadi sangat penting bagi perusahaan untuk beroperasi dengan se-ekonomis mungkin dan perusahaan tidak akan mengalami kesulitan atau menghadapi bahaya-bahaya yang mungkin timbul karena adanya krisis atau kekacauan keuangan. Akan tetapi adanya modal kerja yang berlebihan terutama modal kerja dalam bentuk uang tunai dan surat berharga dapat merugikan perusahaan karena menyebabkan berkumpulnya dana yang besar tanpa penggunaaan secara produktif (Munandar, Huda, \& Arir, 2019). Hal ini menyebabkan hilangnya kesempatan perusahaan untuk memperoleh keuntungan. Di samping itu kelebihan modal kerja juga akan menimbulkan inefisiensi atau pemborosan dalam operasi perusahaan. Salah satu tujuan dari sebuah perusahaan adalah mendapatkan keuntungan yang maksimal. Keuntungan atau laba merupakan sarana penting untuk mempertahankan kelangsungan hidup perusahaan. Makin tinggi laba yang diharapkan maka perusahaan akan mampu bertahan hidup, tumbuh dan berkembang serta tangguh menghadapi persaingan. Maka dengan itu diperlukan manajemen dengan tingkat efektifitas yang tinggi untuk mencapai tujuan perusahaan tersebut. Untuk itu penulis ingin menguji seberapa efektif dan efisien Perusahaan Makanan dan Minuman yang terdaftar di BEI dalam menghasilkan laba dan seberapa mampu laba perusahaan tersebut membiayai kegiatan perusahaan dalam pengembalian investasinya (Rachmawati, 2013). Berikut perhitungan dari laporan keuangan Perusahaan Makanan dan Minuman yang terdaftar di Bursa Efek Indonesia periode tahun 2014-2017 dalam penelitian ini ditekankan pada Perputaran Kas, Perputaran Modal Kerja, dan Return On Investment diperoleh perhitungan sebagai berikut:

Tabel 1. Perputaran Kas, Modal Kerja, ROI Perusahaan Makanan dan Minuman Yang Terdaftar di BEI Periode 2014-2017

\begin{tabular}{|c|c|c|c|c|c|c|}
\hline \multirow[b]{2}{*}{ NO } & \multirow[b]{2}{*}{$\begin{array}{c}\text { KODE } \\
\text { PERUSAHAAN }\end{array}$} & \multirow[b]{2}{*}{$\begin{array}{c}\text { NAMA } \\
\text { PERUSAHAAN }\end{array}$} & \multirow[b]{2}{*}{ TAHUN } & \multicolumn{3}{|c|}{ VARIABEL - VARIABEL } \\
\hline & & & & $\begin{array}{l}\text { PERPUTARAN } \\
\text { KAS (X1) }\end{array}$ & $\begin{array}{c}\text { PERPUTARAN } \\
\text { MODAL KERJA } \\
(\mathrm{X} 2)\end{array}$ & $\mathrm{ROI}(\mathrm{Y})$ \\
\hline \multirow{4}{*}{1} & \multirow{4}{*}{ ROTI } & \multirow{4}{*}{$\begin{array}{l}\text { PT NIPPON } \\
\text { INDOSARI } \\
\text { TBK }\end{array}$} & 2014 & 14.26 & 16.68 & 0.09 \\
\hline & & & 2015 & 6.42 & 5.21 & 0.10 \\
\hline & & & 2016 & 4.48 & 4.01 & 0.10 \\
\hline & & & 2017 & 1.99 & 1.93 & 0.03 \\
\hline \multirow{4}{*}{2} & \multirow{4}{*}{ DLTA } & \multirow{4}{*}{$\begin{array}{l}\text { PT DELTA } \\
\text { DJAKARTA }\end{array}$} & 2014 & 2.07 & 1.33 & 0.29 \\
\hline & & & 2015 & 1.54 & 0.92 & 0.15 \\
\hline & & & 2016 & 1.34 & 0.85 & 0.21 \\
\hline & & & 2017 & 1.03 & 0.73 & 0.21 \\
\hline \multirow{4}{*}{3} & \multirow{4}{*}{ MYOR } & \multirow{4}{*}{$\begin{array}{l}\text { PT MAYORA } \\
\text { INDAH TBK }\end{array}$} & 2014 & 11.01 & 4.17 & 0.04 \\
\hline & & & 2015 & 12.37 & 3.44 & 0.11 \\
\hline & & & 2016 & 11.38 & 3.78 & 0.11 \\
\hline & & & 2017 & 11.12 & 3.36 & 0.11 \\
\hline \multirow{4}{*}{4} & \multirow{4}{*}{ SKLT } & \multirow{4}{*}{$\begin{array}{l}\text { PT SEKAR } \\
\text { LAUT TBK }\end{array}$} & 2014 & 83.53 & 26.21 & 0.05 \\
\hline & & & 2015 & 99.60 & 24.33 & 0.05 \\
\hline & & & 2016 & 81.51 & 15.62 & 0.04 \\
\hline & & & 2017 & 70.55 & 16.43 & 0.04 \\
\hline \multirow{4}{*}{5} & \multirow{4}{*}{ STTP } & \multirow{4}{*}{$\begin{array}{l}\text { PT SIANTAR } \\
\text { TOP TBK }\end{array}$} & 2014 & 222.62 & 8.32 & 0.07 \\
\hline & & & 2015 & 268.09 & 7.93 & 0.10 \\
\hline & & & 2016 & 152.08 & 7.24 & 0.07 \\
\hline & & & 2017 & 59.66 & 4.80 & 0.09 \\
\hline 6 & ULTP & PT & 2014 & 7.12 & 3.40 & 0.10 \\
\hline
\end{tabular}




\begin{tabular}{|c|c|c|c|c|c|c|}
\hline & & \multirow{4}{*}{$\begin{array}{c}\text { ULTRAMILK } \\
\text { INDUSTRY } \\
\text { AND TRADING } \\
\text { COMPANY } \\
\text { TBK }\end{array}$} & & & \\
\hline & & & 2015 & 6.57 & 2.85 & 0.15 \\
\hline & & & 2016 & 3.95 & 2.05 & 0.17 \\
\hline & & & 2017 & 2.68 & 1.86 & 0.14 \\
\hline \multirow{4}{*}{7} & \multirow{4}{*}{ INDF } & \multirow{4}{*}{$\begin{array}{c}\text { PT } \\
\text { INDOFOOD } \\
\text { SUKSER } \\
\text { MAKMUR TBK }\end{array}$} & 2014 & 4.57 & 3.46 & 0.06 \\
\hline & & & 2015 & 4.70 & 3.62 & 0.04 \\
\hline & & & 2016 & 5.04 & 6.83 & 0.06 \\
\hline & & & 2017 & 5.19 & 6.45 & 0.06 \\
\hline \multirow{4}{*}{8} & \multirow{4}{*}{ ICBP } & \multirow{4}{*}{$\begin{array}{c}\text { PT } \\
\text { INDOFOOD } \\
\text { CBP SUKSES } \\
\text { MAKMUR TBK }\end{array}$} & 2014 & 4.67 & 4.05 & 0.10 \\
\hline & & & 2015 & 4.23 & 3.99 & 0.11 \\
\hline & & & 2016 & 4.29 & 3.78 & 0.23 \\
\hline & & & 2017 & 4.15 & 3.65 & 0.21 \\
\hline \multirow{4}{*}{9} & \multirow{4}{*}{ CEKA } & \multirow{4}{*}{$\begin{array}{l}\text { PT WILMAR } \\
\text { CAHAYA } \\
\text { INDONESIA } \\
\text { TBK }\end{array}$} & 2014 & 129.15 & 11.06 & 0.03 \\
\hline & & & 2015 & 180.92 & 7.98 & 0.07 \\
\hline & & & 2016 & 261.31 & 6.86 & 0.18 \\
\hline & & & 2017 & 254.24 & 7.83 & 0.08 \\
\hline \multirow{4}{*}{10} & \multirow{4}{*}{ SKBM } & \multirow{4}{*}{$\begin{array}{l}\text { PT SEKAR } \\
\text { BUMI TBK }\end{array}$} & 2014 & 13.65 & 12.08 & 0.14 \\
\hline & & & 2015 & 11.71 & 31.46 & 0.05 \\
\hline & & & 2016 & 14.85 & 29.85 & 0.02 \\
\hline & & & 2017 & 9.87 & 5.67 & 0.02 \\
\hline
\end{tabular}

Sumber: Data BEI Diolah (2019).

Masalah yang diidentifikasi pada penelitian ini antara lain: (1) kondisi turun atau naiknya perputaran kas pada Perusahaan Makanan dan Minuman yang terdaftar di Bursa Efek Indonesia (BEI) Periode tahun 2014-2017; (2) kondisi turun atau naiknya perputaran modal kerja pada Perusahaan Makanan dan Minuman yang terdaftar di Bursa Efek Indonesia (BEI) Periode tahun 2014-2017; dan (3) kondisi turun atau naiknya return on investment pada Perusahaan Makanan dan Minuman yang terdaftar di Bursa Efek Indonesia (BEI) Periode tahun 2014-2017. Perbedaan penelitian ini adalah menggunakan proksi return pengukuran perputaran kas dan modal kerja dapat mengevaluasi imbas hasil investasi dalam satuan Return on Investement dalam memprediksi perputaran kas dan modal kerja, dimana beberapa penelitian terdahulu menggunakan proksi Return on Assets dalam mengukur profitabilitas perusahaan. Penelitian ini bertujuan untuk mengetahui pengaruh secara parsial dan simultan perputaran kas, perputaran modal kerja dan Return on Investment (ROI) pada Perusahaan Makanan dan Minuman yang terdaftar di Bursa Efek Indonesia (BEI). Penelitian ini diharapkan dapat menjadi masukan bagi perusahaan untuk mengelola kas dan modal kerja dan investor sebagai bahan pertimbangan dalam mengambil keputusan penting mengenai imbas hasil investasi.

\section{Tinjauan Pustaka}

\subsection{Definisi Laporan Keuangan}

Laporan Keuangan merupakan suatu informasi yang menggambarkan kondisi keuangan suatu perusahaan, dan lebih jauh informasi tersebut dapat dijadikan sebagai gambaran kinerja keuangan perusahaan tersebut (Fahmi, 2015, hal. 2) sedangkan laporan keuangan juga menunjukkan kondisi keuangan perusahaan pada saat ini atau dalam suatu periode tertentu (Kasmir, 2016, hal. 7). Berdasarkan pendapat-pendapat para ahli diatas, dapat disimpulkan bahwa laporan keuangan merupakan laporan yang disusun dengan tujuan memberikan gambaran tentang kondisi keuangan pada saat itu dan dapat juga dijadikan gambaran kinerja keuangan perusahaan. 


\section{Buana Akuntansi}

Aria Aji Priyanto

Vol. 5 No. 1

ISSN 2528-1119

E-ISSN 2580-5452

\subsection{Analisis Rasio Keuangan}

Analisis Rasio Keuangan merupakan instrumen analisis prestasi perusahaan yang menjelaskan berbagai hubungan dan indikator keuangan, yang ditujukan untuk menunjukkan perubahan dalam kondisi keuangan atau prestasi operasi di masa lalu dan membantu menggambarkan trend pola perubahan tersebut, untuk kemudian menunjukkan risiko dan peluang yang melekat pada perusahaan yang bersangkutan (Warsidi \& Pramuka, 2000; Fahmi, 2015). Rasio keuangan adalah future oriented atau berorientasi dengan masa depan, artinya bahwa dengan analisa rasio keuangan bisa digunakan sebagai alat untuk meramalkan keadaan keuangan serta hasil usaha dimasa mendatang. Dengan angka-angka rasio historis atau kalau memungkinkan dengan angka rasio industri (yang dilengkapi data lainnya) bisa digunakan sebagai dasar untuk penyusunan laporan keuangan yang diproyeksikan merupakan salah satu bentuk perencanaan keuangan perusahaan (Munawir, 2010, hal. 106).

Metode dan Teknik Analisis Laporan Keuangan terdiri dari: (1) Analisa Horisontal, yaitu analisa dengan mengadakan perbandingan laporan keuangan untuk beberapa periode atau beberapa saat, sehingga akan diketahui perkembangannya. Biasa disebut juga dengan metode analisis dinamis; dan (2) Analisa Vertikal, yaitu laporan keuangan yang dianalisis hanya meliputi satu periode atau satu saat saja, dengan membandingkan antara pos yang satu dengan pos yang lainnya dalam laporan keuangan tersebut, sehingga akan diketahui dengan keuntungan didapat atau hasil operasi pada saat itu saja. Disebut juga dengan analisa statis karena kesimpulan yang dapat diperoleh hanya untuk periode itu saja tanpa mengetahui pertimbangannya (Rachmawati D. W., 2017).

\subsection{Perputaran Kas}

Menurut Rahman (2013:132) kas adalah pembayaran yang siap dan bebas digunakan untuk membiayai kegiatan umum perusahaan. Manajemen kas adalah suatu sistem pengelola perusahaan yang mengatur arus kas (cash flow) untuk mempertahankan likuiditas perusahaan serta memanfaatkan idle cash dan perencanaan cash. Manajer keuangan harus mampu untuk mengelola uang yang masuk ke perusahaan dan uang yang dikeluarkan (Ulorlo, 2012). Dalam penyusunan laporan perubahan kas atau laporan sumber dan penggunaan kas dapat dilakukan dengan meringkas jurnal penerimaan kas dan jurnal pengeluaran kas. Cara ini sangat memakan waktu yang lama karena harus menggolongkan setiap transaksi kas menurut sumber masing-masing serta tujuannya, dan cara ini hanya dapat dilakukan oleh internal analisis yang memungkinkan memperoleh datanya dengan lengkap dan masih murni. Bagi eksternal analisis, menyusun laporan dan penggunaan kas dapat dilakukan dengan menganalisis perubahan yang terjadi dalam laporan keuangan yang diperbandingkan antara dua waktu atau akhir periode serta informasi-informasi lain yang mendukung terjadinya perubahan tersebut. Dalam menganalisis perubahan yang terjadi harus diperhatikan kemungkinan adanya perubahan atau transaksi yang tidak mempengaruhi kas (non cash transaction) (Hidayat, 2018, hal. 30).

Kas kecil adalah salah satu kategori kas yang sangat penting dimanayang dicadangkan perusahaan untuk membayar pengeluaran yang sifatnya rutin tapi jumlah rupiahnya relatif kecil. Kas kecil memiliki beberapa karekteristik diantaranya: (1) jumlahnya dibatasi tidak lebih dan tidak kurang dari suatu jumlah tertentu yang telah ditentukan oleh manajemen perusahaan. Tentunya masing-masing perusahaan menetapkan jumlah yang berbeda sesuai dengan skala operasional perusahaan; (2) dipergunakan untuk mendanai atau membiayai transaksi kecil yang sifatnya rutin setiap hari.

Dua metode pencatatan kas kecil diantaranya adalah: (1) Metode Imprest (Sistem Dana Tetap), yaitu metode pengisian dan pengendalian kas kecil yang dimana kas kecil selalu tetap dan tidak berubah, karena pengisian kembali kas kecil akan selalu sama dengan jumlah yang telah dikeluarkan. Penggunaan kas kecil dicatat dengan metode imprest metode ini tidak 


\section{Buana Akuntansi}

Aria Aji Priyanto

Vol. 5 No. 1

ISSN 2528-1119

E-ISSN 2580-5452

memerlukan pencatatan (jurnal) atas setiap transaksi yang terjadi; dan (2) Metode Fluktuasi, yaitu metode pencatatan dan pengendalian kas kecil yang dimana jumlah kas kecil akan selalu berubah karena pengisian kembali kas kecil selalu sama dari waktu ke waktu. Setiap pengeluaran yang mempergunakan kas kecil harus selalu dicatat atau dijurnal berdasakan bukti transaksi yang ada satu per satu (Prabowo, 2018).

\subsection{Perputaran Modal Kerja}

Sri Dwi Ari Ambarwati (2010:112) berpendapat bahwa modal kerja adalah modal yang seharusnya tetap ada dalam perusahaan sehingga operasional perusahaan menjadi lebih lancar serta tujuan akhir perusahaan untuk menghasilkan laba akan tercapai. Investasi yang ditanamkan dalam aktiva lancar atau aktiva jangka pendek, seperti kas, bank, surat-surat berharga, piutang, persediaan, dan aktiva lancar lainnya disebut sebagai modal kerja (Kasmir, 2016, hal. 250). Analisis sumber dan penggunaan modal kerja merupakan analisis yang mempunyai hubungan dengan sumber-sumber dana dan penggunaan dana yang berkaitan dengan modal kerja perusahaan. Artinya dari mana saja perusahaan memperoleh dana guna membiayai kegiatannya. Kemudian, dana yang sudah diperoleh akan digunakan untuk aktivitas apa saja. Perolehannya dana yang dibutuhkan perusahaan cukup banyak tersedia dan untuk memperolehnya relatif tidak terlalu sulit selama masih memenuhi persyaratan yang dipersyaratkan. Hanya saja dari berbagai sumber yang ada perlu di seleksi terlebih dahulu. Artinya pemilihan setiap sumber dana yang akan digunakan disesuaikan dengan kebutuhan perusahaan. Di samping itu juga, perlu dipikirkan untung ruginya penggunaan sumber dana yang akan dipilih. Pentingnya manajemen modal kerja perusahaan, terutama bagi kesehatan keuangan dan kinerja perusahaan adalah:

1. Bahwa kegiatan seorang manajer keuangan lebih banyak dihabiskan didalam kegiatan operasional perusahaan dari waktu ke waktu, atau dengan kata lain sebagian besar waktu di alokasikan untuk mengelola modal kerja.

2. Investasi dalam aktiva lancar, cepat sekali berubah dan sering kali berubah dan mengalami perubahan serta cenderung labil. Perubahan tersebut akan berpengaruh terhadap modal kerja perusahaan. Oleh karena itu, perlu manajemen modal mendapat perhatian yang sungguh-sungguh dari manajer keuangan.

3. Dalam praktiknya sering kali bahwa lebih dari separuh total aktiva merupakan bagian dari aktiva lancar yang merupakan modal kerja perusahaan. Artinya, jumlah aktiva lancar sama atau lebih dari 50\% dari total aktiva. Dengan kata lain, lebih dari separuh jumlah aktiva di investasikan dalam aktiva lancar.

4. Khusus bagi perusahaan kecil manajemen modal kerja sangat penting karena investasi dalam aktiva tetap dapat ditekan dengan menyewa, tetapi investasi lancar dalam piutang dan persediaan tidak dapat dihindarkan harus segera terpenuhi.

5. Bagi perusahaan yang relatif kecil fungsi modal kerja juga amat penting. Hal ini disebabkan perusahaan kecil, relatif terbatas untuk memasuki pasar dengan modal besar dan jangka panjang. Pendanaan perusahaan lebih mengandalkan pada hutang jangka pendek, seperti hutang dagang, hutang bank satu tahun yang tentunya dapat mempengaruhi modal kerja.

6. Terdapat hubungan yang sangat erat antara pertumbuhan penjualan dengan kebutuhan modal kerja. Kenaikan penjualan berkaitan tambahan, piutang, persediaan, dan juga saldo kas. Demikian pula sebaliknya apabila terjadi penurunan penjualan, maka akan berpengaruh terhadap komponen dalam aktiva lancar (Kasmir, 2016, hal. 300).

2.5. Profitabilitas

37 IJurnal Buana Akuntansi 


\section{Buana Akuntansi}

Aria Aji Priyanto

Vol. 5 No. 1

ISSN 2528-1119

E-ISSN 2580-5452

Return On Investment adalah salah satu bentuk dari pengukuran profitabilitas yang dimaksudkan untuk mengukur kemampuan perusahaan dengan keseluruhan dana yang ditanamkan dalam aktiva yang digunakan untuk operasi perusahaan dalam menghasilkan keuntungan (Munawir, 2010, hal. 89). Return On Investment sebagai bentuk teknik analisa rasio profitabilitas sangat penting dalam suatu perusahaan karena dengan mengetahui Return On Investment, pengusaha dapat mengetahui seberapa efisien perusahaan guna memanfaatkan aktiva untuk kegiatan operasional dan dapat memberikan informasi ukuran profitabilitas perusahaan. Analisis Return On Investment juga mempunyai beberapa kegunaan diantaranya adalah:

1. Jika perusahaan telah menjalankan praktik akuntansi yang baik, maka manajemen degan menggunakan teknik Analisa ROI dapat mengukur efisiensi penggunaan modal yang bekerja, efisiensi produksi, dan efisiensi bagian penjualan.

2. Apabila perusahaan mempunyai data industri sehingga dapat diperoleh rasio industri, maka dengan analisa $\mathrm{ROI}$ dapat dibandingkan efisiensi penggunaan modal pada perusahaannya dengan perusahaan lain yang sejenis, sehingga dapat diketahui apakah perusahaannya berada dibawah, sama, atau diatas rata-rata. Dengan demikian akan dapat diketahui dimana kelemahan dan kekuatan perusahaan dibandingkan dengan perusahaan lain yang sejenis.

3. Analisa ROI juga dapat digunakan untuk mengukur efisiensi tindakan-tindakan yang dilakukan oleh masing-masing divisi atau bagian, yaitu dengan mengalokasikan semua biaya dan modal ke dalam bagian yang bersangkutan.

4. Analisa ROI juga dapat digunakan untuk mengukur profitabilitas dari masing-masing produk yang dihasilkan oleh perusahaan.

5. ROI selain berguna untuk keperluan kontrol, juga berguna untuk keperluan perencanaan. Misalnya ROI dapat digunakan sebagai dasar untuk pengambilan keputusan jika perusahaan akan mengadakan ekpansi (Ningrum, 2014).

\subsection{Hasil Penelitian Terdahulu}

Penelitian dengan menguji pengaruh Perputaran Modal Kerja dan Perputaran Kas terhadap Profitabilitas Perusahaan yang mengukur kinerja keuangan perusahaan dengan menggunakan Working Capital Turnover Ratio, Cash Turnover Ratio dan Return On Asset dengan temuan penelitian menunjukkan variabel perputaran modal kerja dan variabel perputaran kas berpengaruh terhadap profitabilitas (ROA) dengan R-square sebesar 0.431 , perputaran modal kerja 20,144920 dan perputaran kas senilai 33,717649 pada perusahaan manufaktur sementara perputaran modal kerja 6,542924 dan perputaran kas 10,487194 pada perusahaan properti sehingga perusahaan manufaktur lebih unggul dibandingkan dengan perusahaan properti (Fayani, Sukesti, \& Hanum, 2013). Penelitian dengan menguji pengaruh Perputaran Modal Kerja, Perputaran Kas, Perputaran Piutang, dan Perputaran Persediaan terhadap Profitabilitas pada Perusahaan Manufaktur yang Terdaftar di BEI periode tahun 2011-2015 yang melibatkan 20 sampel perusahaan dengan temuan penelitian yaitu perputaran modal kerja berpengaruh positif terhadap ROA, perputaran kas berpengaruh negatif terhadap ROA, perputaran piutang berpengaruh negatif terhadap ROA dan persediaan berpengaruh positif terhadap ROA (Natalia, Rahardjo, \& Supriyanto, 2017). Penelitian dengan menguji pengaruh Manajemen Modal Kerja terhadap Profitabilitas Perusahaan Studi Kasus pada Perusahaan Makanan dan Minuman yang terdaftar di BEI periode 2011-2015 yang melibatkan 12 dari 14 sampel perusahaan dengan temuan penelitian yaitu variabel perputaran modal kerja memiliki pengaruh positif dan signifikan sedangkan perputaran kas dan perputaran persediaan memiliki pengaruh negatif dan signifikan terhadap profitabilitas (ROI) (Sapetu, Saerang, \& Soepeno, 2017). 


\section{Buana Akuntansi}

\subsection{Rerangka Penelitian}

Rerangka penelitian merupakan implementasi kerangka berpikir yang baik akan menjelaskan secara teoritis hubungan antara variabel yang akan diteliti. Menurut Uma Sekaran (dalam Sugiyono, 2018:91) kerangka berfikir merupakan model konseptual tentang bagaimana teori berhubungan dengan berbagai faktor yang telah didefinisikan sebagai masalah yang penting.

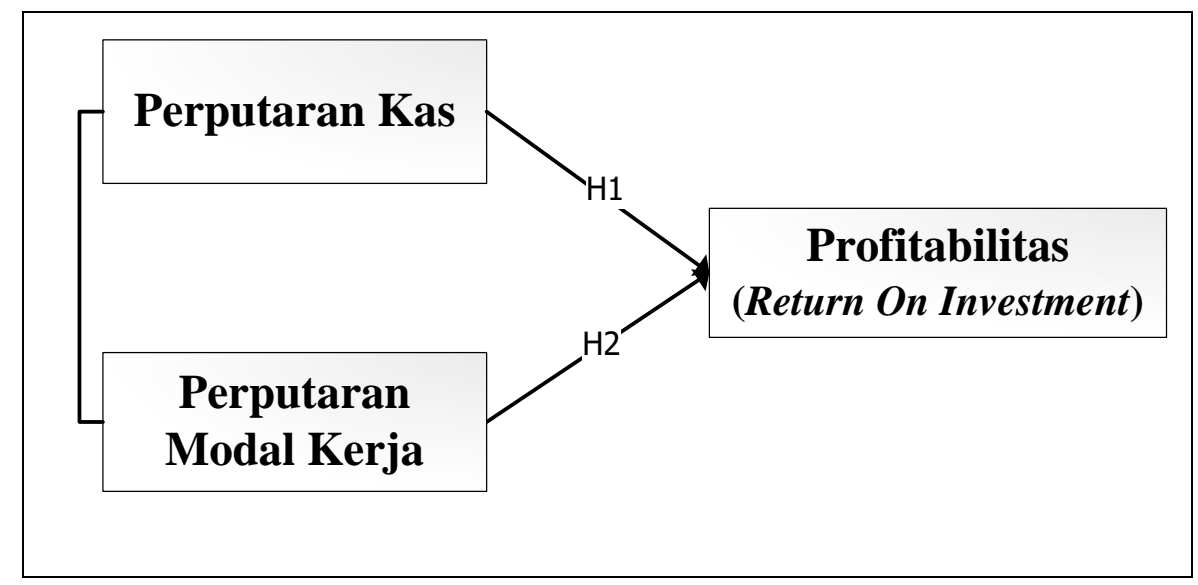

Gambar 1: Rerangka Penelitian

Rerangka penelitian di atas diturunkan ke dalam perumusan hipotesis berikut ini:

$\mathrm{H}_{1}$ : Perputaran Kas berpengaruh terhadap Profitabilitas (Return On Investment)

$\mathrm{H}_{2}$ : Perputaran Modal Kerja berpengaruh terhadap (Return On Investment)

\section{Metodologi Penelitian}

\subsection{Jenis Penelitian}

Penelitian ini merupakan tipe kausalitas, yaitu tipe penelitian dengan tujuan menguji hipotesis tentang pengaruh satu variabel atau beberapa variabel (variable independent) terhadap variabel lainnya atau variable dependent (Sugiyono, 2018, hal. 62). Penelitian ini menggunakan pendekatan kuantitatif dimana merupakan serangkaian observasi atau pengukuran hasilnya menggunakan data sekunder yang diperoleh dari laporan keuangan perusahaan yang listing di Bursa Efek Indonesia (BEI).

\subsection{Populasi dan Sampel}

Berdasarkan subjek penelitian yang telah ditetapkan, maka populasi yang menjadi objek penelitian ini adalah perusahaan yang tergolong dalam perusahaan yang bergerak dibidang industri makanan dan minuman yang terdaftar di Bursa Efek Indonesia selama 4 (empat) periode, yaitu tahun 2014 - 2017. Populasi dalam penelitian ini berjumlah 18 perusahaan. Sampel adalah "Bagian dari jumlah dan karakteristik yang dimiliki oleh populasi" (Sugiyono, 2018, hal. 62). Pada penelitian ini, metode purposive sampling digunakan dengan pertimbangan kriteria-kriteria, yaitu: (1) perusahaan makanan dan minuman yang telah terdaftar di Bursa Efek Indonesia dan telah didaftarkan di audit pada periode 2014 - 2017.; (2) perusahaan yang mempunyai laporan keuangan yang lengkap periode 2014-2017; (3) perusahaan yang tidak mengalami kerugian dari tahun 2014-2017; dan (4) perusahaan yang mempunyai perputaran modal kerja positif selama tahun 2014-2017. Perusahaan yang menjadi objek penelitian dan memenuhi kriteria sampling yaitu 10 (sepuluh perusahaan). 


\section{Buana Akuntansi}

\subsection{Metode Pengumpulan Data}

Metode pengumpulan data menggunakan studi kepustakaan yaitu suatu teknik pengumpulan data yang bertujuan untuk memperoleh keterangan dengan cara membaca dan mempelajari buku-buku dan sumber-sumber tertulis lainnya yang berhubungan dengan masalah penelitian. Kemudian, studi dokumentasi untuk memperoleh dan mendapatkan data yang valid, maka peneliti melakukan penelitian di Bursa Efek Indonesia (BEI) guna memperoleh dan mendapatkan data yang diperlukan, yaitu berupa laporan keuangan per 31 Desember 2014 sampai dengan 31 Desember 2017 pada Perusahaan Makanan dan Minuman yang terdaftar di Bursa Efek Indonesia.

\subsection{Operasionalisasi Variabel Penelitian}

Variabel Perputaran Kas (X1) didefinisikan sebagai rasio yang digunakan untuk mengukur tingkat kecukupan modal kerja perusahaan yang dibutuhkan untuk membayar tagihan dan membiayai penjualan. Secara matematis, Perputaran Kas dapat dirumuskan sebagai berikut:

$$
\text { Perputaran Kas }=\frac{\text { PenjualanBersih }}{\text { Rata-Rata Kas }}(\text { Kasmir, 2016) }
$$

Variabel Modal Kerja (X2) didefinisikan sebagai rasio yang digunakan untuk mengukur atau menilai keefektifan modal kerja berputar selama satu periode. Secara matematis, Perputaran Modal Kerja dapat dirumuskan sebagai berikut:

$$
\text { Perputaran Modal Kerja }=\frac{\text { PenjwalanBersih }}{\text { Modal Kerja }} \text { (Fahmi, 2015) }
$$

Variabel Profitabilitas dengan Return On Investment $(\mathrm{Y})$ didefinisikan perbandingan antara laba bersih setelah pajak dengan total aset.

\subsection{Metode Analisis Data}

Metode analisis data menggunakan data panel (pooled data) yaitu gabungan dari data runtut waktu (time series) dan data silang (cross section) kemudian pengujian hipotesis dilakukan dengan menggunakan regresi data panel dengan tahapan sebagai berikut:

1) Model estimasi regresi data panel dapat dilakukan melalui 3 (tiga) pendekatan antara lain: (a) common Effect Model, dengan rumus: $Y_{i t}=\alpha+X^{1}$ it $\beta i t+\varepsilon_{i t}$; (b) Fixed Effect Model, dengan rumus: Yit $=\alpha+i \alpha_{1}+X^{1}$ it $\beta i t+\varepsilon_{i t}$; dan (c) Random Effect Model, dengan rumus: $Y$ it $=X^{1}$ it $\beta i t+v_{i t}$; dimana $v_{i t}=\mathrm{c}_{i}+\mathrm{d}_{t}+\varepsilon_{i t}$ (Basuki, 2016, hal. 276-277).

2) Estimasi pemilihan model data panel dapat dilakukan melalui 3 (tiga) teknik antara lain: (a) Uji-Chow, dengan rumus $=\frac{N-1}{N T-N-K}$; (b) Uji Hausman, dengan rumus $=W=\left(\beta_{\mathrm{FEM}}-\right.$ $\left.\beta_{\mathrm{REM}}\right)^{\prime} \Psi^{-1}\left[\beta_{\mathrm{FEM}}-\beta_{\mathrm{FEM}}\right]$; dan (c) Uji Lagrange Multiplier (LM) dengan rumus:

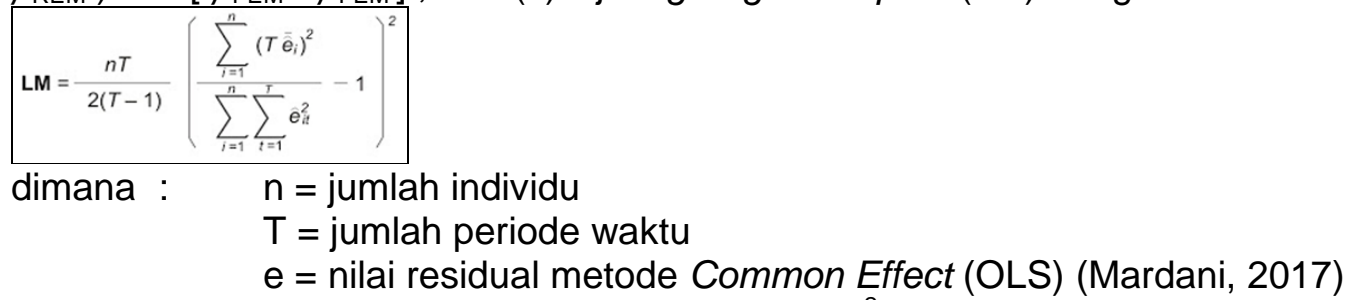

3) Uji hipotesis melalui uji Koefisien Determinasi $\left(R^{2}\right)$, Uji simultan (Uji-F) dan Uji parsial (uji-t). 


\section{Buana Akuntansi}

Aria Aji Priyanto

Vol. 5 No. 1

ISSN 2528-1119

E-ISSN 2580-5452

\section{Hasil dan Pembahasan}

4.1. Hasil Penelitian

18 perusahaan manufaktur sub sektor Makanan dan Minuman yang tercatat di Bursa Efek Indonesia periode 2014-2017, tetapi yang menjadi objek penelitian ini yaitu 10 (sepuluh) dengan menggunakan metode purposive sampling.

Tabel 2. Data Sampel Perusahaan

\begin{tabular}{|c|c|l|}
\hline No & Kode Saham & \multicolumn{1}{c|}{ Nama Emiten } \\
\hline 1 & ROTI & PT. Nippon Indosari Tbk. \\
\hline 2 & DLTA & PT. Delta Djakarta \\
\hline 3 & MYOR & PT. Mayora Indah Tbk. \\
\hline 4 & SKLT & PT. Sekar Laut Tbk. \\
\hline 5 & STTP & PT. Siantar Top Tbk. \\
\hline 6 & ULTP & PT. Ultra Milk Industry and Trading Company \\
\hline 7 & INDF & PT. Indofood Sukses Makmur Tbk. \\
\hline 8 & ICBP & PT. Indofood CBP Sukses Makmur Tbk. \\
\hline 9 & CEKA & PT. Wilmar Cahaya Indonesia Tbk. \\
\hline 10 & SKBM & PT. Sekar Bumi Tbk. \\
\hline
\end{tabular}

Sumber: Data BEI Diolah (2019).

Pemilihan Model Regresi Data Panel dirangkum pada tabel berikut:

Tabel 3. Rangkuman Hasil Uji Estimasi

\begin{tabular}{lcl}
\multicolumn{1}{c}{ Metode } & Model Estimasi yang Diuji & Hasil / Keputusan \\
\hline Uji Chow (uji statistik F) & CEM vs FEM & Fixed-Effect Model \\
\hline Uji Hausman & CEM vs REM & Random-Effect Model \\
\hline Uji Lagrange Multiplier (LM) & FEM vs REM & Random-Effect Model \\
\hline
\end{tabular}

Sumber: Data Diolah Eviews 9 (2019).

Hasil uji Chow menghasilkan keputusan pemilihan Fixed-Effect Model (FEM), akan tetapi pada uji Hausman menghasilkan keputusan pemilihan Random-Effect Model (REM). Uji Lagrange Multiplier (LM) yang dikonfirmasikan ulang juga menghasilkan menghasilkan keputusan pemilihan Random-Effect Model (REM). Oleh karena itu, pengujian hipotesis dengan analisis regresi data panel lebih tepat menggunakan model Random-Effect pada penelitian ini.

Analisis regresi data panel digunakan untuk mengetahui arah pengaruh antara variabel independen dan variabel dependen. Model regresi yang digunakan adalah model RandomEffect (REM).

Tabel 4. Random-Effect Model (REM)

Dependent Variable: $Y$

Method: Panel EGLS (Cross-section random effects)

Date: 02/20/19 Time: 22:27

Sample: 20142017

Periods included: 4

Cross-sections included: 10

Total panel (balanced) observations: 40

Swamy and Arora estimator of component variances

\begin{tabular}{llllll}
\hline \hline & Variable & Coefficient & Std. Error & t-Statistic & Prob. \\
\hline \hline $\mathrm{C}$ & 0.119592 & 0.018206 & 6.568681 & 0.0000
\end{tabular}

41 IJurnal Buana Akuntansi 


\section{Buana Akuntansi}

Aria Aji Priyanto

Vol. 5 No. 1

ISSN 2528-1119

\begin{tabular}{lllll}
$\mathrm{X} 1$ & $3.58 \mathrm{E}-05$ & 0.000145 & 0.246361 & 0.8068 \\
$\mathrm{X} 2$ & -0.002459 & 0.001285 & -1.913679 & 0.0634 \\
\hline \hline
\end{tabular}

\begin{tabular}{lll}
\hline \hline & Effects Specification & \\
& S.D. & Rho \\
\hline \hline Cross-section random & 0.038300 & 0.4395 \\
Idiosyncratic random & 0.043253 & 0.5605 \\
\hline \hline
\end{tabular}

\begin{tabular}{lcll}
\hline \hline \multicolumn{4}{c}{ Weighted Statistics } \\
\hline \hline R-squared & 0.084027 & Mean dependent var & 0.050152 \\
Adjusted R-squared & 0.034515 & S.D. dependent var & 0.045725 \\
S.E. of regression & 0.044929 & Sum squared resid & 0.074688 \\
F-statistic & 1.697108 & Durbin-Watson stat & 1.454507 \\
Prob(F-statistic) & 0.197164 & & \\
\hline
\end{tabular}

\begin{tabular}{llll}
\hline \hline \multicolumn{4}{c}{ Unweighted Statistics } \\
\hline \hline R-squared & 0.192310 & Mean dependent var & 0.102000 \\
Sum squared resid & 0.130555 & Durbin-Watson stat & 0.832094 \\
\hline \hline
\end{tabular}

Sumber: Output Eviews 9 (2019).

Hasil Estimasi Regresi Data Panel untuk Random-Effect Model (FEM) pada tingkat alpha ( $\alpha=$ $0,05)$ dirangkum sebagai berikut:

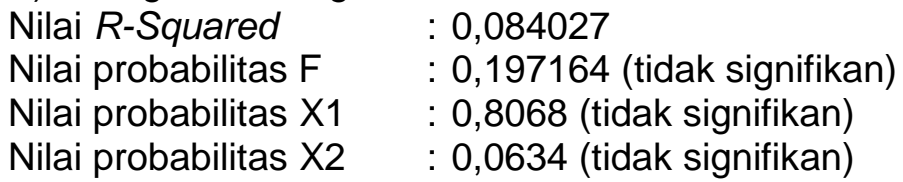

Nilai $R$-Squared menunjukkan seberapa besar variabel bebas mampu menjelaskan varian atas variabel terikat. Hasil analisis model regresi data panel secara keseluruhan menghasilkan nilai $R^{2}$ sebesar 0,084027 yang menunjukkan bahwa variabel bebas Perputaran Kas (X1) dan Perputaran Modal Kerja (X2) hanya mampu menjelaskan Return On Investment (ROI) sebagai variabel terikat sebesar 8,40 persen sedangkan sisanya sebesar 91,60 persen dipengaruhi oleh variabel lainnya yang tidak diikusertakan pada penelitian ini.

Nilai F-statistics untuk variabel Perputaran Kas (X1) dan Perputaran Modal Kerja (X2) secara simultan diperoleh sebesar 1,697108 dengan probabilitas signifikansi sebesar 0,197164. Nilai probabilitas signifikansi sebesar 0,197164 lebih besar dari $\alpha=0,05$ artinya Perputaran Kas dan Perputaran Modal Kerja secara simultan tidak berpengaruh terhadap Return On Investment (ROI).

Pembuktian uji hipotesis atas variabel Perputaran Kas dan perputaran Modal Kerja pada 10 (sepuluh) perusahaan sub sektor makanan dan minuman yang terdaftar di BEI periode 20142017 yaitu:

Hipotesis ke-1: nilai t-statistics atas variabel Perputaran Kas (X1) diperoleh sebesar positif 0,246361 dengan probabilitas signifikansi sebesar 0,8068 . Nilai probabilitas signifikansi sebesar 0,8068 lebih besar dari $\alpha=0,05$ sehingga menolak $\mathbf{H}_{1}$. Hipotesis ini secara statistik tidak membuktikan Perputaran Kas berpengaruh terhadap Profitabiltias dengan Return On Investment (ROI).

Hipotesis ke-2: nilai t-statistics atas variabel Perputaran Modal Kerja (X2) diperoleh sebesar negatif 1,913679 dengan probabilitas signifikansi sebesar 0,0634 . Nilai 


\section{Buana Akuntansi}

Aria Aji Priyanto

Vol. 5 No. 1

ISSN 2528-1119

E-ISSN 2580-5452

probabilitas signifikansi sebesar 0,0634 lebih besar dari $\alpha=0,05$ sehingga

menolak $\mathbf{H}_{2}$. Hipotesis ini secara statistik tidak membuktikan Perputaran Modal Kerja berpengaruh terhadap Profitabiltias dengan Return On Investment (ROI).

\subsection{Pembahasan}

Variabel Perputaran Kas (X1) dengan membandingkan penjualan bersih dengan rata--rata kas yang tersedia melalui pembuktian hipotesis ke-1 menunjukkan bahwa tidak terjadinya pengaruh signifikan Perputaran Kas terhadap Profitabiltias dengan Return On Investment (ROI) sehingga peningkatan atau penurunan perputaran kas tidak berdampak terhadap ROI. Dalam aktivitas perusahaan kas merupakan aktiva yang paling liquid yang dimiliki oleh perusahaan untuk kebutuhan operasionalnya sehingga tidak tersedianya kas yang dialokasikan untuk aktivitas investasi membuat return on investment yang dihasilkan perusahaan makanan dan minuman sangat minim sekali. Temuan penelitian mengkonfirmasi hasil yang bertolak-belakang yaitu pengaruh negatif perputaran kas terhadap ROA dan ROI (Natalia, Rahardjo, \& Supriyanto, 2017; Sapetu, Saerang, \& Soepeno, 2017).

Variabel Perputaran Modal (X2) dengan membandingkan penjualan bersih dengan modal kerja melalui pembuktian hipotesis ke-2 menunjukkan bahwa tidak terjadinya pengaruh signifikan Perputaran Modal Kerja terhadap Profitabiltias dengan Return On Investment (ROI) sehingga peningkatan dan penurunan yang ada tidak mempengaruhi ROI. Dalam aktivitas perusahaan modal kerja merupakan salah satu yang digunakan untuk memenuhi kewajiban yang dimiliki suatu perusahaan sehingga banyak modal kerja yang tidak dialokasikan untuk investasi yang dihasilkan perusahaan makanan dan minuman sangat minim sekali. Temuan penelitian juga mengkonfirmasi hasil yang bertolak-belakang yaitu pengaruh positif perputaran modal kerja terhadap ROA dan ROI (Natalia, Rahardjo, \& Supriyanto, 2017; Sapetu, Saerang, \& Soepeno, 2017).

\section{Kesimpulan, Keterbatasan, dan Saran}

Berdasarkan hasil penelitian, maka penelitian ini disimpulkan sebagai berikut:

a. Perputaran Kas tidak berpengaruh terhadap Profitabilitas

b. Perputaran Modal kerja tidak berpengaruh terhadap Profitabilitas

Berdasarkan kesimpulan dari penelitian, maka kelemahan penelitian ini yang dapat diagendakan pada penelitian mendatang antara lain:

a. Variabel perputaran kas dan perputaran modal kerja tidak mampu memprediksi variabel profitabilitas yang diproksikan dengan Return on Investment yang dibuktikan dengan ujiF dengan nilai probabilitas signifikansi yang lebih besar dari 0,05 sehingga berdampak pada faktor perputaran kas dan perputaran modal kerja yang juga tidak berpengaruh terhadap profitabilitas. Penelitian mendatang hendaknya merumuskan atau menambahkan pengukuran perputaran kas dan modal kerja dengan melibatkan proksi Return on Assets yang mencerminkan perputaran aset-aset perusahaan sehingga mampu memberikan hasil yang representatif menggambarkan secara umum perusahaan-perusahaan yang terdaftar di Bursa Efek Indonesia.

b. Variabel perputaran kas dan perputaran modal kerja hanya menghasilkan nilai R-square yang sangat rendah yaitu 8,4 persen sehingga kedua rasio perputaran ini tidak mampu memprediksi pengaruhnya terhadap profitabilitas perusahaan yang diproksikan dengan Return on Investment. Peneliti mendatang hendaknya dapat memprediksi dengan lebih baik dan melibatkan faktor-faktor lainnya dalam mempengaruhi profitabilitas perusahaan dengan Return On Investment. 
c. Perusahaan sebaiknya tidak perlu terlalu banyak mengendapkan dana di dalam kas dan modal kerja, karena berdasarkan hasil penelitian yang ada, meningkatnya perputaran kas tidak berpengaruh terhadap Return On Investment ROI dan sebaiknya. Perusahaan dapat menggunakan kelebihan dana pada kas untuk menambah persediaan ataupun hal lainnya yang dapat meningkatkan kapasitas modal kerja untuk mencapai hasil produksi yang berdampak pada meningkatkan laba pada perusahaan.

\section{Daftar Pustaka}

Ambarwati, S. D. (2010). Manajemen Keuangan Lanjut. Yogyakarta: Graha Ilmu.

Arifianti, R. (n.d.). Modul 1: Definisi Strategi Produksi dan Keputusan Strategi Produksi/Operasi. Retrieved Juni 27, 2019, from http://www.pustaka.ut.ac.id/lib/wp-content/uploads/pdfmk/ ADBI443403-M1.pdf

Ayem, S., Wahyuni, T., \& Suyanto. (2017). Pengaruh Quick Ratio, Debt to Equity Ratio, Inventory Turnover, dan Net Profit Margin terhadap Pertumbuhan Laba Pada Perusahaan Manufaktur yang Terdaftar Di Bursa Efek Indonesia Tahun 2011-2015. Jurnal Akuntansi Dewantara, 1 (2), 117-126.

Basuki, A. T. (2016). Analisis Regresi Dalam Penelitian Ekonomi E Bisnis: Dilengkapi Aplikasi SPSS $\mathcal{E}$ EVIEWS. Depok: PT Rajagrafindo Persada.

Bulan, T. P. (2015). Pengaruh Modal Kerja terhadap Tingkat Profitabilitas pada PT Adira Dinamika Multi Finance Tbk. Jurnal Manajemen dan Keuangan, 4 (1).

Djannah, R. (2017). Pengaruh Kinerja Keuangan Terhadap Pertumbuhan Laba pada Perusahaan Food and Beverage. Jurnal Ilmu \& Riset Manajemen , 6 (7), 1-16.

Erawati, T., \& Widayanto, I. J. (2016). Pengaruh Working Capital To Total Asset, Operating Income To Total Liabilities, Total Asset Turnover, Return On Asset, Dan Return On Equity Terhadap Pertumbuhan Laba Pada Perusahaan Manufaktur Yang Terdaftar Di Bursa Efek Indonesia. JURNAL AKUNTANSI, 4 (2), 49-60.

Fahmi, I. (2015). Analisis Laporan Keuangan. Bandung: Alfabeta.

Fayani, D. M., Sukesti, F., \& Hanum, A. N. (2013). Pengaruh Perputaran Modal Kerja dan Perputaran Kas terhadap Profitabilitas Perusahaan (Studi kasus pada perusahaan properti dan perusahaan manufaktur yang terdaftar pada BEI tahun 2010-2012). MAKSIMUM: Media Akuntansi Universitas Muhammadiyah, 3 (2), 51-68.

Hidayat, W. W. (2018). Dasar-Dasar Analisa Laporan Keuangan (Cetakan kedua). Ponorogo: Uwais Inspirasi Indonesia.

Kasmir, D. (2016). Analisis Laporan Keuangan. Jakarta: PT. Rajagrafindo Persada.

Kementerian Perencanaan Pembangunan Nasional/Badan Perencanaan Pembangunan Nasional. (2018). Masterplan Ekonomi Syari'ah Indonesia 2019-2024. Deputi Bidang Ekonomi. Jakarta: Kementerian Perencanaan Pembangunan Nasional/Badan Perencanaan Pembangunan Nasional.

Khaldun, K. I., \& Muda, I. (2014). The Influence Of Profitability And Liqudity Ratios On The Growth Of Profit Of Manufacturing Companies. International Journal of Economics, Commerce and Management, II (12), 1-17.

Marantika, A. (2015). Analisis Efisiensi Penggunan Modal Kerja Dan Profitabilitas Efficiency Analysis Of The Use Of Working Capital And Profitability. JMK, 10 (2), 54-64. 
Mardani, R. (2017). Penggunaan EViews - Memilih Model Regresi Data Panel. Retrieved Oktober 22, 2019, from https:/ / mjurnal.com/memilih-model-regresi-data-panel/

Mukhtarom, A. E., Kusumaningrum, S., \& Ifanani, A. (2015). Analisis Laporan Arus Kas Untuk Menilai Kinerja Keuangan Koperasi Pegawai Republik Indonesia Kokeda Kabupaten Tegal. $e^{-}$ Journal Politeknik Tegal, 4 (1), 47-54.

Munandar, A., Huda, N., \& Arir, M. V. (2019). Efisiensi Penggunaan Modal Kerja pada PT. Holcim Tbk. Jurnal Manajemen dan Keuangan, 8 (1), 89-98.

Munawir, S. (2010). Analisis Laporan Keuangan. Yogyakarta: Liberty.

Natalia, K. V., Rahardjo, K., \& Supriyanto, A. (2017). Pengaruh Perputaran Modal Kerja, Perputaran Kas, Perputaran Piutang, dan Perputaran Persediaan terhadap Profitabilitas pada Perusahaan Manufaktur yang Terdaftar di BEI periode tahun 2011-2015. Jurnal Ilmiah Mahasiswa S1 Akuntansi Universitas Pandanaran, 3 (2), 1-17.

Ningrum, F. S. (2014). Analisis Return On Investment (ROI) untuk Menilai Profitabilitas pada Perusahaan Perbankan yang Terdaftar di Bursa Efek Indonesia 2009-2013. Sinki Universitas Nusantara PGRI Kediri.

Prabowo, E. (2018). Analisis Penerapan Akuntansi Kas Kecil dalam Menunjang Efektivitas Pengelolaan Kas Kecil pada PT. Nusa Pusaka Kencana Kebun Bahilang - Asian Agri Tebing Tinggi. FEB. Medan: Repository USU.

Rachmawati, D. W. (2017). Evaluasi Kinerja Keuangan PT Pupuk Driwijaya Dilihat dari Rasio Likuiditas. Jurnal Manajemen Indonesia, 17 (3), 205-218.

Rachmawati, E. (2013). Analisis Efektivitas Penggunaan Modal Kerja pada PT. Fresmon Pasifik di Samarinda. Ekonomia, 2 (1), 44-50.

Rahman, A. 2. (2013). Psikologi Sosial. Jakarta: Rajagrafindo Persada.

Sapetu, Y., Saerang, I. S., \& Soepeno, D. (2017). Pengaruh Manajemen Modal Kerja terhadap Profitabilitas Perusahaan Studi Kasus pada Perusahaan Makanan dan Minuman yang terdaftar di BEI periode 2011-2015. Jurnal EMBA, 5 (2), 1440 -1451.

Siti, R. W. (2018). Pengaruh Perputaran Modal Kerja Terhadap Profitabilitas Pada Perusahaan Manufaktur Sektor Industri Barang Konsumsi yang Terdaftar di Bursa Efek Indonesia periode 20122016. Fakultas Ekonomi. Jawa Timur: Universitas Muhammadiyah Ponorogo.

Sugiyono. (2018). Metode Penelitian Evaluasi: Pendekatan Kuantitatif, Kualitatif, dan Kombinasi. Bandung: CV. Alfabeta.

Ulorlo, L. (2012). Pengaruh Arus Kas Operasi dan Manajemen Aset Terhadap Kemampulabaan, Pertumbuhan Perusahaan. Program Studi Manajemen Keuangan. Bogor: Repositori STIE Kesatuan.

Warsidi, \& Pramuka, B. A. (2000). Evaluasi Kegunaan Rasio Keuangan dalam Memprediksi Perubahan Laba di Masa yang Akan Datang: Suatu Studi Empiris pada Perusahaan yang Terdaftar di BEJ. Retrieved Oktober 22, 2019, from: http://warsidi-akuntan.tripod.com/ skrpsi/skripsi.htm 